\title{
PENGARUH PEMBERIAN KORO BENGUK (Mucuna pruriens L) TERHADAP KADAR GULA DARAH TIKUS DIABETES MELITUS YANG DIINDUKSI STREPTOZOTOCIN
}

\author{
The Influence Of Blowed Coro (Mucuna Pruriens L) On Blood Sugar Levels Of Diabetes Mellitus Diabetes \\ Induced By Streptozotocin
}

1*Endang Widhiyastuti, ${ }^{2}$ Mastuti Widi Lestari,

${ }^{1}$ D IV Teknologi Laboratorium Medis, STIKES Nasional, Jl. Solo Baki, Jawa Tengah, Indonesia

${ }^{2}$ D IV Teknologi Laboratorium Medis, STIKES Nasional, Jl. Solo Baki, Jawa Tengah, Indonesia

*e-mail : Dr.endangwidhiyastuti@yahoo.co.id

\begin{abstract}
ABSTRAK
Diabetes yang terkenal di masyarakat dengan sebutan penyakit kencing manis di Indonesia adalah suatu penyakit kronik, yang terjadi ketika pankreas tidak memproduksi cukup insulin atau ketika tubuh tidak dapat memanfaatkan insulin hasil produknya sendiri. Pemberian antioksidan pada tikus DM dapat menurunkan kadar gula darah. Salah satu tanaman herbal yang dapat digunakan untuk pengendalian dan penatalaksanaan gula darah pada pada kondisi diabetes adalah koro benguk. Koro Benguk (Mucuna pruriens L) adalah tanaman yang dapat dijadikan alternatif dalam pengobatan karena memiliki kandungan antioksidan yang dapat menjaga kesehatan tanpa menimbulkan efek toksisitas. Tujuan dari penelitian ini adalah untuk mengetahui apakah ada pengaruh pemberian kopi koro benguk (Mucuna pruriens L) terhadap kadar gula darah Tikus Diabetes Mellitus Yang Diinduksi Streptozotocin. Penelitian ini merupakan penelitian eksperimen terhadap tikus Sprague Dawley. Sebanyak 35 tikus wistar jantan dibagi ke dalama 5 kelompok masing-masing : kontrol normal (K1); kontrol diabetes (K2); tikus diabetes diberi infusa kopi koro benguk 0,63 mg/ g BB tikus (P1); tikus diabetes diberi infusa kopi koro benguk 1,26 mg/ g BB tikus (P2). Tikus diabetes diberi infusa kopi koro benguk20,52 mg/ g BB tikus. Kadar glukosa darah puasa (GDP) dianalisa perminggu selama 3 minggu dengan metode GOD-PAP. Hasil dari penelitian ada penurunan gula darah selama 4 kali waktu pengamatan pada hampir seluruh kelompok perlakuan kecuali kelompok kontrol positif. Kesimpulan dalam penelitian ini pemberian kopi koro benguk (Mucuna pruriens L) dapat menurunkan kadar glukosa darah puasa pada tikus Sprague Dawley model diabetes secara signifikan dibandingkan dengan kontrol.
\end{abstract}

Kata kunci : diabetes mellitus, kopi koro benguk (Mucuna pruriens L), streptozotocin , gula darah

\begin{abstract}
Diabetes which is well-known in the community as diabetes in Indonesia is a chronic disease, which occurs when the pancreas does not produce enough insulin or when the body cannot utilize the insulin produced by its own products. The Provision of antioxidants in DM mice can reduce blood sugar levels. One of the herbs that can be used for control and management of blood sugar in diabetes is swollen koro. Koro Benguk (Mucuna pruriens L) is a plant that can be used as an alternative treatment because it contains antioxidants that can maintain health without causing toxic effects. The purpose of this study was to determine whether there is an effect of giving koro benguk coffee (Mucuna pruriens L) on blood sugar levels of Streptozotocin-induced Diabetes Mellitus Rats. This study is an experimental study of Sprague Dawley mice. A total of 35 male wistar rats were divided into 5 groups each: normal control (K1); diabetes control (K2); diabetic rats were given a large coffee extract $0.63 \mathrm{mg} / \mathrm{g} \mathrm{BW}$ rat (P1); diabetic rats were given a large infusion of coffee koro $1.26 \mathrm{mg} / \mathrm{g}$ BW rats (P2). Diabetic rats were given an infusion of coffee koro benguk20,52 $\mathrm{mg} / \mathrm{g}$ BW rats. Fasting blood glucose (GDP) levels were analyzed weekly for 3 weeks using the GOD-PAP method. The results of the study showed a decrease in blood sugar for 4 times the observation time in almost all treatment groups except the positive control group. The conclusions in this study were the provision of related coffee (Mucuna pruriens L) can reduce fasting blood glucose levels in Sprague Dawley rats with diabetes models significantly compared to controls.
\end{abstract}

Keyword: diabetes mellitus, koro benguk coffee (Mucuna pruriens L), Streptozotocin, blood sugar 


\section{PENDAHULUAN}

Diabetes yang terkenal di masyarakat dengan sebutan penyakit kencing manis di Indonesia adalah suatu penyakit kronik, yang terjadi ketika pankreas tidak memproduksi cukup insulin atau ketika tubuh tidak dapat memanfaatkan insulin hasil produknya sendiri (WHO, 2011). Diabetes Melitus adalah masalah utama di dunia dikarenakan jumlah penderita yang sangat banyak dan terus meningkat dan jika tidak ditangani dengan baik dengan pengobatan akan menimbulkan komplikasi. Sedangkan biaya pengobatannya sangat mahal (PERKENI, 2015).

Berdasarkan data Kementrian Kesehatan (2014) kejadian penyakit diabetes mellitus di Indonesia tahun 2013 sebesar 2,1\%. Angka tersebut lebih tinggi dibandingkan dengan tahun 2007 (1,1\%). Sebanyak 93,9\% provinsi menunjukkan kenaikan prevalensi diabetes mellitus yang cukup berarti, diantaranya Provinsi Jawa Tengah sebesar 1,9\%. Jumlah kasus DM tipe 2 di Jawa Tengah tahun 2015 sebanyak 99.646 kasus, meningkat dibandingkan tahun 2014 (96.431 kasus).

Obat Antidiabetik Oral saat ini banyak dipakai untuk pengendalian penyakit diabetes mellitus. Namun penggunaanya memiliki beberapa kekurangan diantaranya harga yang sangat mahal, efikasi yang tidak adekuat, banyak menimbulkan efek samping seperti toksik terhadap hepar, asidosislaktat ataupun diare, gangguan kardiovaskuler (Patel et al., 2008; Rao et al, 2008, Nahas \& Moher, 2009; McCreight et al, 2016).

Salah satu tanaman herbal yang dapat digunakan untuk pengendalian dan penatalaksanaan diabetes adalah koro benguk. Koro Benguk (Mucuna pruriens L) adalah tanaman yang dapat dijadikan alternatif dalam pengobatan karena memiliki kandungan antioksidan yang dapat menjaga kesehatan tanpa menimbulkan efek toksisitas (Jain, 2011).Biji koro benguk terkandung senyawa fenolik. Hasil penelitian in vitro menunjukkan bahwa ekstrak metanol biji koro benguk (Mucuna pruriens) memiliki aktivitas antioksidan. Kandungan total fenolik dari ekstrak metanol biji kacang koro menggunakan uji Folin-Ciocalteau menunjukkan $33,04 \mathrm{mg} / \mathrm{g}$. Ekstrak metanol biji koro benguk pada konsentrasi $100 \mu \mathrm{g} / \mathrm{mL}$ mempunyai kemampuan memerangkap radikal bebas 1,1-diphenyl-2-picrylhydrazyl (DPPH) sebesar 90,16 \% (Rajeshwar, et.al., 2005). Apabila di dalam tubuh terdapat radikal bebas dapat memicu kejadian stress oksidatif. Stress Oksidatif memiliki kontribusi pada perburukan dan perkembangan kejadian komplikasi diabetes mellitus. Sehingga untuk meredam kerusakan oksidatif tersebut diperlukan antioksidan (Matough et al., 2012;).

Pada penelitian ini biji kacang koro benguk diubah kedalam bentuk kopi, dikarenakan kopi sendiri merupakan minuman kesukaan hampir sebagai besar masyarakat di Indonesia, selaian itu biji koro benguk yang sudah dibuat dalam bentuk kopi memiliki nilai kecernaan yang tinggi. Pemanfaatan kopi koro benguk dalam menurunkan kadar glukosa darah sudah diterapkan oleh sebagaian masyarakat yang terkena Diabetes Melitusdi daerah Sumberlawang Sragen, Jawa tengah, Namum selama ini belum ada penelitian yang membuktikan pemanfaatan kopi koro benguk dalam menurunakan kadar gula darah.

\section{METODE PENELITIAN}

\section{Jenis Penelitian}

Penelitian ini merupakan penelitian eksperimen terhadap tikus Sprague Dawley.. Kadar glukosa darah puasa (GDP) dianalisa perminggu selama 3 minggu dengan metode GOD-PAP.

\section{Populasi dan Sampel}

Populasi yang digunakan dalam penelitian ini adalah tikus Sprague Dawley Sebanyak 35 tikus wistar jantan dibagi ke dalama 5 kelompok masingmasing : kontrol normal (K1); kontrol diabetes (K2); tikus diabetes diberi infusa kopi koro benguk 0,63 mg/g BB tikus (P1); tikus diabetes diberi infusa kopi koro benguk $1,26 \mathrm{mg} / \mathrm{g}$ BB tikus (P2). Tikus diabetes diberi infusa kopi koro benguk $20,52 \mathrm{mg} / \mathrm{g}$ BB tikus. 
BJMLT

\section{Instrumen Penelitian}

\section{Alat}

Alat yang digunakan dalam penelitian ini yaitu, kompor listrik merk Maspion, beaker glass, spuit 1 cc, glukometer, alcohol swab, jarum/lancet, timbangan BC 500, kandang tikus polypropyelene, AC, lampu, nipple,scalpet, pinset anatomis, gunting, jarum, meja lilin, handscoon, sentrifuge, spektrofotometer UV-Visibel (AE LAB-S80-1S), kertas saring, alat-alat gelas berupa labu ukurIwaky Pyrex $50 \mathrm{ml}$ dan $200 \mathrm{ml}$, gelas ukurIwaky Pyrex 10 $\mathrm{ml}$, gelas bekerIwaky Pyrex, corong, tabung reaksi, batang pengaduk, oven, botol vial,spatula.

\section{Bahan}

Bahan dasar yang digunakan dalam penelitian ini adalah koro benguk bubuk, streptozotocin (Cayman chemical company), Buffer $\mathrm{pH} \mathrm{4,} \mathrm{air} \mathrm{panas,} \mathrm{tikus}$ Sprague Dawley, pakan BR 1, darah vena tikus, $\mathrm{NaCl}$, formalin $70 \%$, organ hepar dan pankreas, 0,15 $\mathrm{M}$ Tris $\mathrm{HCl}$, supernatan, dithiobisnitrobenzoate, sodium dinitrate, TCA (Trichloroacetic acid), TBA (Thiobarbituric acid), $\mathrm{HCl}$ (Hydorchloric acid).

\section{Analisis Data}

Data dikumpulkan dan dianalisis secara statistik dengan uji normalitas dan uji homogenitas untuk memenuhi asumsi uji parametrik yaitu data berdistribusi normal dan homogen. Kemudian dilakukan uji ANOVA.

\section{HASIL DAN PEMBAHASAN}

Kadar glukosa darah adalah salah satu penilaian kondisi diabetes. Tikus yang mendapatkan induksi streptoztocin (STZ) menunjukkan peningkatan kadar glukosa. Streptozotocin merupakan turunan nitrosourea diisolasi dari kapang Streptomyces griseus, secara selektif toksik terhadap sel beta pankreas tidak menyebabkan kerusakan pada sel endokrin lain maupun pada parenkim eksokrin (Szkudelski, 2001; Lenzen,2008).

Berdasarkan uji coba in vitro menunjukkan bahwa induksi streptozotocin menyebabkan peningkatan konsumsi Oksigen dan menghasilkan radikal H2O2 (Szkudelski, 2001). Hal tersebut berlanjut pada kerusakan sel beta pankreas sehingga produksi dan aksi insulin menurun. Kondisi ini menimbulkan gangguan pada metabolisme karbohidrat, lemak dan protein dan bermanifestasi pada peningkatan kadar gula darah. Biji koro benguk memiliki kandungan antioksidan yang dapat mengurangi kerusakan sel beta pankreas pada tikus hiperglikemi (Retnaning, 2011).

Hasil pengukuran kadar glukosa darah puasa (GDP) pada tikus dengan perlakuan kontrol negatif $(\mathrm{K}-)$, kontrol positif $(\mathrm{K}+)$, kopi koro benguk dosis 0,63 mg/g BB tikus(P1), kopi koro benguk dosis 1,26 $\mathrm{mg} / \mathrm{g}$ BB tikus(P2) dan kopi koro benguk dosis 2,52 $\mathrm{mg} / \mathrm{g}$ BB tikus (P3) disajikan dalam tabel 1 berikut :

TABEL 1. Hasil Pemeriksaan Gula Darah Tikus Sprague Dawley Minggu ke-0 sampai minggu ke-4

\begin{tabular}{|c|c|c|c|c|c|}
\hline \multirow[t]{3}{*}{ Kelompok } & \multicolumn{4}{|c|}{ Glukosa Darah (gram) } & \multirow[t]{3}{*}{$\mathbf{P}$} \\
\hline & \multicolumn{4}{|l|}{ Minggu ke- } & \\
\hline & 0 & 1 & 2 & 3 & \\
\hline $\mathrm{K}-)^{*}$ & $218,80 \pm 9,85$ & $105,00 \pm 9,38$ & $88,20 \pm 10,89$ & $88,00 \pm 19,02$ & 0,014 \\
\hline $\mathrm{K}+$ & $210,02 \pm 8,83$ & $269,2 \pm 217,29$ & $248,00 \pm 268,14$ & $80,60 \pm 81,90$ & 0,086 \\
\hline P1 & $212,50 \pm 8,57$ & $386,2 \pm 251,77$ & $270,80 \pm 178,88$ & $66,4 \pm 63,05$ & 0,021 \\
\hline P2 & $207,58 \pm 9,61$ & $388,40 \pm 255,14$ & $72,4 \pm 161,89$ & $21,00 \pm 46,95$ & 0,020 \\
\hline P3 & $215,70 \pm 5,57$ & $337,2 \pm 229,90$ & $277,80 \pm 215,51$ & $96,20 \pm 60,32$ & 0,035 \\
\hline
\end{tabular}

Hasil dari penelitian pengaruh kopi koro benguk benguk (Mucuna pruriens) kadar glukosa darah terendah di dapatkan pada hari ke-21. Kelompok kontrol negatif menunjukkan kadar glukosa normal yaitu $<200 \mathrm{gl} / \mathrm{dl}$. Keadaan ini merupakan gambaran bahwa organ pancreas masih memiliki fungsi yang normal dalam mengatur kadar glukosa darah. Dalam keadaan normal, glukosa dari makanan ditransportasikan menuju vena porta oleh transporter glukosa yang terdapat pada usus (Oran, 2007). Salah satu hormon yang berperan dalam mengatur kadar glukosa darah adalah insulin dan glukagon. Dalam keadaan normal, produksi insulin oleh sel $\beta$ meningkat sebanding dengan meningkatnya kadar glukosa dalam darah. Adapun hormon glukagon akan banyak diproduksi pada saat kadar glukosa dalam darah rendah. Regulasi dari produksi hormon insulin dan glukagon akan menjaga kadar glukosa darah dalam keadaan normal (James, 2010).

Pada kontrol positif kadar GDP masih mengalami penurunan mulai minggu ke-2 sampai minggu ke-4. Hal ini berarti menunjukkan bahwa kontrol positif mampu menjadi pembanding bagi perlakuan dengan menggunakan infusa kopi koro benguk (Mucuna pruriens)dan menunjukkan bahwa dosis STZ yang diberikan mampu bekerja maksimal 
merusak sel beta pancreas. Pada perlakuanmenggunakan dengan memberikan infusa kopi koro benguk (Mucuna pruriens) dengan dosis $0,63 \mathrm{mg} / \mathrm{g}$ BB tikusdidapatkan hasil bahwa kadar gula darah puasa tikus mengalami penurunan.Perlakuan ini menunjukkan bahwa infusa kopi koro benguk dengan dosis $0,63 \mathrm{mg} / \mathrm{g}$ BB tikus terlihat berpotensi menurunkan kadar glukosa darah puasa. Begitu pula dengan perlakuan yang diberikan dosis infusa kopi koro benguk (Mucuna pruriens)dosis 1,26 mg/g BB tikus dan 2,52 mg/g BB tikus juga menunjukkan hal yang sama, dimana terjadi penurunan kadar gula darah puasa.

Penurunan kadar glukosa darah tersebut dikarenakan kandungan senyawa antioksidan yang ada di dalam tempe koro benguk. Menurut Pinent, dkk. (2008) dalam penelitian in vitro bahwa genistein yang terdapat pada isoflavon mampu meningkatkan sekresi insulin pada MIN6 (mouse-derived) line sel beta pankreas dari mencit yang dikulturkan hingga konsentrasi $100 \mu \mathrm{mol} / \mathrm{L}$. Mineral yang ada dalam tempe koro benguk seperti $\mathrm{Na}, \mathrm{K}, \mathrm{Ca}, \mathrm{Zn}, \mathrm{MG}, \mathrm{Fe}, \mathrm{P}$, $\mathrm{Cu} \mathrm{Mn}$ dan $\mathrm{Cr}$ membantu mekanisme pelepasan insulin sehingga menurunkan kadar glukosa (Pinent, dkk. 2008). Selain itu sifat hipoglikemi tersebut juga karena adanya senyawa D-chiroinositol di dalam Mucuna pruriens L (Donati, et.al. 2005).

Komposisi zat gizi yang terkandung dalam bijikoro benguk diantaranya : protein (24-31,44\%), karbohidrat (42,79-64,88\%), lemak (4,1-14,39\%), serat $(5,3-11,5 \%)$, mineral, asam amino dan abu (2,9-5,5\%) (Artari, 2017). Kandungan isoflavon seperti daidzi, genistein faktor-II (6,7,4-trihydroxy isoflavone), dan glycitein (senyawa antioksidan pada kedelai) juga terdapat pada koro benguk. Kandungan daidzin dan genistein pada koro benguk lebih tinggi dibandingkan kedelai. Tempe koro benguk juga memiliki faktor-II (6,7,4-trihydroxy isoflavone) dan genistein lebih tinggi dibandingkan tempe kedelai. Hal tersebut menunjukkan bahwa koro benguk berpotensi sebagai alternatif pengganti kedelai. Tempe koro benguk dengan kandungan gizi yang baik dan seimbang dapat menjadi pilihan pangan terkait dengan pengembangan pangan lokal untuk mendampingi tempe kedelai (karena sebagian besar kedelai diperoleh dari impor). (Retnaningsih, 2007). Selain itu, keunggulan biji koro benguk mengandung senyawa fenolik. Berdasarkan hasil penelitian in vitro menunjukkan bahwa ekstrak metanol biji koro benguk (Mucuna pruriens) mempunyai aktivitas antioksidan. Kandungan total fenolik dari ekstrak metanol biji kacang koro menggunakan uji Folin-Ciocalteau menunjukkan $33,04 \mathrm{mg} / \mathrm{g}$. Ekstrak metanol biji koro benguk pada konsentrasi $100 \mu \mathrm{g} / \mathrm{mL}$ mempunyai kemampuan memerangkap radikal bebas 1,1-diphenyl-2-picrylhydrazyl (DPPH) sebesr 90,16 \% (Rajeshwar, dkk., 2005).

Biji Koro Benguk banyak terkandung antioksidan, senyawa yang mampu menangkal radikal bebas. Radikal bebas adalah atom atau molekul yang memiliki elektron yang tidak berpasangan dan bersifat dapat menarik elektron dari senyawa lain sehingga terbentuk radikal bebas yang baru. Radikal bebas yang sangat reaktif bersifat tidak stabil, berumur sangat pendek dan sulit dideteksi. Contoh senyawa reaktif misalnya gugus hidroksil ($\mathrm{OH})$, radikal peroksil $(\mathrm{OOH})$, ion superoksida $(\mathrm{O} 2$. ), Hidrogen peroksida (H2O2), dan lain-lain. Keberadaan radikal bebas dalam tubuh dapat menyebabkan terjadinya penyakit degeneratif, misalnya jantung, diabetes, ateroskelorosis, kanker dan sebagainya. Bahkan radikal bebas ini dapat merusak selaput sel dan asam dioksi ribonukleat (DNA) (Percival, 1998; Agbafor dan Nwachukwu, 2011). Senyawa aktif yang bersifat antioksidan yang ada di dalam koro benguk ini terdapat dalam bentuk isoflavon. Senyawa tersebut masuk dalam kelompok flavonoid, senyawa polifenolik yang umumnya terdapat di dalam buah-buahan, sayur-sayuran, dan biji-bijian (Shahidi, 1999; Bors, et.al., 2001; Miller, 2002).

\section{KESIMPULAN}

Koro benguk memiliki kandungan gizi yang baik dan seimbang dengan kadar protein dan karbohidrat yang tinggi dan kadar lemak yang rendah. Pada tikus yang mendapat perlakuan kopi koro benguk dengan dosis $0,63 \mathrm{mg} / \mathrm{g}$ BB tikus, 1,26 $\mathrm{mg} / \mathrm{g}$ BB tikus dan $2,52 \mathrm{mg} / \mathrm{g}$ BB tikus mengalami penurunan kadar glukosa darah bermakna dibandingkan kelompok kontrol positif $(\mathrm{C}+)$. 


\section{BJMLT}

\section{DAFTAR PUSTAKA}

Agbafor,K.N. dan Nwachukwu N. 2011. Phytochemical Analysis and Antioxidant Property of Leaf Extracts of Vitexdoniana and Mucuna pruriens. Research Article. Biochemistry Research International.pp 1-4

Bors, W. C., Michel, K. dan Stettmaier. 2001. Flavonoids and Other Polyphenols. Packer, L.Ed. Academic Press. San Diego.

Guyton, A. C., Hall, J. E. 2014. Buku Ajar Fisiologi Kedokteran. Edisi 12. Jakarta : EGC, 1022

James P, Leu, Joel Zonszein. 2010. Principles of Diabetes Mellitus. New York: Springer Science

Kementerian Kesehatan RI. 2014. Situasi dan Analisis Diabetes. Jakarta: Kementerian Kesehatan RI

Matough, Budin., S.B., Hamid, Z.A., Alwahaibi, N., and Mohamed, J., 2012, The Role of Oxidative Stress and Antioxidants in Diabetic Complications, Sultan Qaboos Univ Med J. 12(1): 5-18.

Miller, A. L. 2002. Antioxidant Flavonoid Structure Function and Clinical Usage. http :// www. Thorne. Com/alt medrev/fulltext/flavonoids 1-2 html. Diunduh tanggal 18 Oktober 2019

Perkumpulan Endokrinologi Indonesia, 2015. Konsensus Pengendalian dan Pencegahan Diabetes Mellitus Tipe 2 di Indonesia. PB. PERKENI. Jakarta
Poitout,V dan Robertson, R. P. 2008. Glucotoxicity: Fuel excess and beta cell dysfunction. Endocrine Reviews 29(3):351-366

Rajeshwar, Y., Kumar, G.P.S., Gupta, M. U. K. dan Mazumber. 2005. Studies on In Vitro Antioxidant Activities of Methanol Extract of Mucuna pruriens (Fabaceae) Seeds. European Bulletin of Drug Research. Vol 13 (1)

Retnaning, C. 2017. Penurunan Kadar Glukosa Pada Tikus Hiperglikemi Dengan Asupan Tempe Koro Benguk (Mucuna pruriens L) Desertasi. Program Studi Teknologi Pangan Fakultas Teknologi Pertanian Unika Soegijapranata

Roy, D. C., Barman, S. K., \& Shaik, M. M. 2013. Current updates on Centella asiatica: Phytochemistry, pharmacology and traditional uses. Medicinal Plant Research, 3, (4), 20-36.

Shahidi, F. 1999. Natural Antioxidants. Chemistry, Health Effect, and Applications, hal 235- 73. AOCS Press. Champaign, Illinois

Szkudelski T. 2012. Streptozotocin- nicotinamideinduced diabetes in the rat. Characteristics of the experimental model. Experimetal Biolology and Medicine 237:481-490

World Health Organization. 2011. Diabetes: The Problem and The Solution. 